\title{
VITAMIN A, IMMUNITY AND INFECTION
}

\section{ANDREW TOMKINS AND GREGORY HUSSEY}

Clinical Nutrition Unit, Centre for Human Nutrition, London School of Hygiene and Tropical Medicine, Keppel Street, London WC1E 7HT

\section{CONTENTS}

INTRODUCTION . . . . . 17

DIETARY SOURCES, ABSORPTION AND EXCRETION . . . . 18 ABSORPTION AND METABOLISM . . . . . . . . . . . . . . 18 TRANSPORT AND DELIVERY . . . . . . . . . . . . . . . . 19

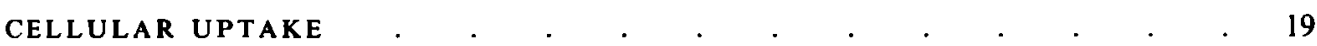
EXCRETION . . . . . . . . . . . . . . . . . . . . . . . 19

ASSESSMENT OF VITAMIN A STATUS . . . . . . . . . . . . 19 CLINICAL ASSESSMENT . . . . . . . . . . . . . . . . . . . 20 FUNCTION OF THE RETINA . . . . . . . . . . . . . . . . . . 20 CONJUNCTIVAL INTEGRITY . . . . . . . . . . . . . . . 21 BIOCHEMICAL ASSESSMENT . . . . . . . . . . . . . . 21

Plasma retinol . . . . . . . . . . . . . . . . . 21

Liver biopsy . . . . . . . . . . . . . . . . . . . 21

Relative dose response . . . . . . . . . . . . . . . . . 21

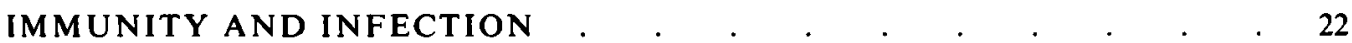

ANIMAL EXPERIMENTAL STUDIES $\quad$. . . . . . . . . . . . . 22

Mucosal surfaces . . . . . . . . . . . . . . . . . . . . . . . . 22

Cell-mediated immunity. . . . . . . . . . . . . . . . . . 22

Humoral immunity . . . . . . . . . . . . . . . . 23

FREE RADICAL SCAVENGING . . . . . . . . . . . . . . . . . 23

MALNUTRITION-INFECTION INTERACTIONS IN MAN . . . . . . 24 EPIDEMIOLOGICAL STUDIES . . . . . . . . . . . . . . . . . 25

VITAMIN A SUPPLEMENTS AND INFECTIONS . . . . . . . . . . . . 25

PREVENTIVE SUPPLEMENTATION WITH VITAMIN A . . . . . . . . 26 REFERENCES . . . . . . . . . . . . . . . . . . . . . . 26

\section{INTRODUCTION}

The importance of vitamin A deficiency as the cause of blindness from xerophthalmia in many areas of the Third World is well recognized. Indeed, it is estimated that more than ten million children develop xerophthalmia each year, and of these half a million become blind. Recently, however, there has been increasing interest in the importance of vitamin $A$ in immunity; several authors have claimed striking reductions in childhood morbidity and mortality among communities who receive regular supplements of vitamin A (Sommer 
et al. 1986; Muhilal et al. 1988). It has been proposed recently that vitamin A supplementation should be incorporated as a regular feature of the Expanded Programme for Immunization of the World Health Organization (WHO) and United Nations (International) Children's (Emergency) Fund (UNICEF) child health and nutrition programmes. The present review will examine recent research on the effect of vitamin $A$ on different components of the immune system and will highlight certain infection-immune reactions where vitamin $A$ appears to be particularly important. In addition it will aim to identify those areas where information is still lacking.

As so often happens, the 'new' emphasis on vitamin A and immunity of the last decade is really a re-discovery of the very clear observation of the anti-infective properties of vitamin A described by Mellanby \& Green in 1929. The bulk of the literature on vitamin A since that time has focused on its role in vision, growth, cellular differentiation, metabolism and reproduction. Its effect on immunity has been largely neglected until recently.

It should be made clear that vitamin $A$ is the general term used to include vitamin $A_{1}$ (retinol and axerophol), which is found in animals and sea fish, and vitamin $A_{2}(3,4-$ dehydroretinol), which is found chiefly in fresh-water fish and which is unimportant in mammals. Provitamin A refers to the plant carotenoids which are converted to vitamin A by mammals. $\alpha$-, $\beta$ - and $\gamma$-carotene and crypto-xanthine appear to be the most active carotenoids. The term retinoids is used to include those naturally occurring substances with vitamin $\mathbf{A}$ activities and the synthetic analogues of vitamin $\mathrm{A}$, with or without biological activity (Goodman, 1984).

There are three main forms of vitamin A, with characteristic activities on individual target organs. Retinal (the aldehyde) affects vision, retinol (the alcohol) affects reproduction and retinoic acid (the acid) affects cellular differentiation and tissue growth (Madani, 1986).

\section{DIETARY SOURCES, ABSORPTION AND EXCRETION}

\section{ABSORPTION AND METABOLISM}

The major natural sources of vitamin $A$ in the diet are the plant carotenoids and the longchain retinyl esters found in animal tissues. Of the carotenoids, $\beta$-carotene is the most useful provitamin. The stability of carotene in the lumen of the intestine is dependent on a number of factors, including the presence of antioxidants. Vitamin $E$ protects carotenes against oxidative destruction (Barker, 1983). $\beta$-Carotene is converted to retinal, primarily in the intestinal mucosa, this process requiring two enzymes, $\beta$-Carotene $15,15^{\prime}$-dioxygenase (EC 1.13.11.21) cleaves the $\beta$-carotene at the central double bond, resulting in two molecules of retinaldehyde which in turn are reduced by retinaldehyde reductase ( $E C$ 1.1.1.71) to retinol. Dietary retinyl esters are hydrolysed by pancreatic esterases in the intestinal lumen, and retinol is absorbed into the mucosal cell (Goodman, 1984). The presence of bile is essential for absorption. Absorption is also age-dependent, being more complete in adults than in children. Cellular retinol-binding protein (RBP), type 2, which is found in the epithelial cells of jejunal villi and to a lesser extent in the ileum, has an important role to play in the reservoir for absorbed retinol and may function actively as well, presenting retinol to the appropriate esterifying enzymes (Ong, 1985).

Re-esterification of the retinol with long-chain fatty acids takes place in the mucosal cell. These complexes are transported in the lymphatics to the liver, which is the major storage organ of retinol. The retinyl esters delivered to the liver are re-esterified and stored in the form of retinyl palmitate in parenchymal liver cells and fat storage cells. 


\section{TRANSPORT AND DELIVERY}

Vitamin $A$ is transported from the liver to the other organs as the free alcohol retinol form bound to the protein carrier, RBP, and circulates as the retinol-RBP complex (holo-RBP) (Ong, 1985). RBP is a single polypeptide chain with a molecular weight of $21000 \mathrm{~d}$ and is synthesized in the liver. Once retinol is delivered to the tissues, RBP is catabolized in the proximal convoluted tubule in the kidneys. RBP circulates with transthyretin (prealbumin). Transthyretin has an important role in the binding and transport of the thyroid hormones, and hence vitamin A has important effects on thyroid status (Goodman, 1984).

Release of RBP into the blood is dependent on the previous formation of the retinol-RBP complex. Retinol deficiency impairs the secretion of RBP so that the plasma level of RBP decreases and the liver level increases. Patients with liver disease, hyperthyroidism or severe protein-energy malnutrition have low levels of circulating RBP, while patients with chronic renal disease and those on oestrogen therapy have high levels of RBP. These findings are a reflection of the balance between synthesis and catabolism of RBP.

\section{CELLULAR UPTAKE}

A number of important binding proteins are necessary for the uptake of retinol into the tissues. In the eye, cellular retinal-binding protein and interstitial RBP have been described. Cellular RBP and cellular retinoic acid-binding protein have been described in other tissues (Ong, 1985). The exact role of the latter two proteins is unknown, but it is postulated that they may serve as intracellular transport proteins and play a role in the biological expression of vitamin $\mathbf{A}$.

The uptake and utilization of vitamin A are complex processes and will not be discussed (Ong, 1985).

\section{EXCRETION}

Vitamin $\mathbf{A}$ and carotenoids are excreted in the urine and bile as inactive metabolites (Orten \& Neuhaus, 1982). These metabolites have not been totally characterized but consist mainly of the decarboxylated products. Increased levels of vitamin A metabolites in the urine have been reported in a number of conditions including pneumonia, nephritis, hepatitis, diabetes and rheumatic fever (Barker, 1983). Faecal excretion also occurs, but this is usually the unabsorbed dietary fraction, especially of $\beta$-carotene.

The mechanism of excess excretion of retinol is not clear. In the liver retinol is conjugated with glucuronic acid and is also oxidized to the aldehyde and acid forms. The oxidized forms and the glucuronides are excreted in the bile and approximately $30 \%$ of retinol glucuronide is recycled back to the liver in an enterohepatic circulation of vitamin $A$. Glucuronides remaining in the bowel are hydrolysed by enteric bacteria and excreted in the stools (Olson, 1987).

\section{ASSESSMENT OF VITAMIN A STATUS}

Vitamin A status is the product of a dynamic process involving intake, storage, mobilization, utilization and excretion, and deficiency occurs when there is an alteration in this process, primarily as a result of depletion of liver stores. Biochemical and clinical evidence of vitamin A deficiency or chronic excess do not occur until there is considerable depletion or saturation of liver stores (Pitt, 1981). An accurate assessment of 
Table 1. Classification of xerophthalmia (from World Health Organization, 1976)

\begin{tabular}{|c|c|c|}
\hline & $\begin{array}{l}\text { XS } \\
\text { X1A } \\
\text { X1B } \\
\text { X2 } \\
\text { X3A } \\
\text { X3B } \\
\text { XS } \\
\text { XF }\end{array}$ & $\begin{array}{l}\text { Night blindness } \\
\text { Conjunctival xerosis } \\
\text { Bitot's spot } \\
\text { Corneal xerosis } \\
\text { Corneal ulceration-keratomalacia }>\frac{1}{3} \text { corneal surface } \\
\text { Corneal ulceration-keratomalacia }<\frac{1}{3} \text { corneal surface } \\
\text { Corneal scar } \\
\text { Xerophthalmic fundus }\end{array}$ \\
\hline
\end{tabular}

hypovitaminosis A can, therefore, only be obtained by a liver biopsy, which is clearly not feasible in the majority of patients and not possible for community surveys. The present available techniques for assessment comprise: (1) clinical; (2) retinal function; (3) conjunctival integrity; (4) biochemical (including plasma retinol, liver retinol, relative dose response and isotope studies); (5) dietary assessment.

\section{CLINICAL ASSESSMENT}

The only clinical feature that is specifically attributable to vitamin A deficiency is xerophthalmia, the collective term for all the eye lesions. Xerophthalmia is usually indicative of advanced vitamin A depletion, thus many individuals who may be biochemically deficient may be clinically normal. Surveys which examine the prevalence of eye disease alone will not, therefore, give a true reflection of the problem of hypovitaminosis $A$, and would ignore a number of people who may be subject to the adverse effects of vitamin A deficiency on immunity. Large population surveys are also necessary to detect clinically significant signs. Despite this shortcoming, clinical assessment is a useful survey technique. To allow for accurate reporting and comparison of information the WHO (1976) has devised a classification system (Table 1).

It has been proposed that a major problem of vitamin A deficiency exists if the following occur: Bitot's spot in more than $2 \%$ of the population; corneal xerosis and corneal ulceration-keratomalacia in more than $0.01 \%$ of the population; corneal scar in more than $0.1 \%$ of the population (WHO, 1976).

A history of night blindness in community surveys has been found to be a useful guide by some research workers, especially in areas where there is a specific local name for this symptom. However, the problems of training staff for accurate ocular examination, the large numbers of subjects that have to be examined if differences in prevalence of xerophthalmia are to be evaluated statistically, and the logistics of such surveys are all disadvantages.

\section{FUNCTION OF THE RETINA}

A number of tests for function of the retina are available. These include dark-adaptation, rod scotometry, electroretinography and reflective spectophotometry. None of these, with the possible exception of dark-adaptation, is suitable as a screening test in community surveys because of the expense of the equipment, the time taken to perform the test and considerable variation in compliance.

However, a rapid test of only 5 min duration has been developed for field use (Vinton \& Russell, 1981), in which there was a good correlation between vitamin A levels and dark- 
adaptation time; but, in a survey in Brazil, Favaro et al. (1986) found no correlation between vitamin A status and dark-adaptation time. A possible reason for this discrepancy is that the former study included adults while the latter was performed on children.

\section{CONJUNCTIVAL INTEGRITY}

Two relatively easy tests of conjunctival integrity are available, these being conjunctival impression cytology and the Rose Bengal test.

The basis of the first test is that vitamin A deficiency causes changes in the conjunctival epithelium, with eventual squamous metaplasia, deficiency of mucus and keratinization. Special papers are touched on the cornea and removed, and adherent cells are stained (Hatchell \& Sommer, 1986; Natadisastra et al. 1987). Wittpenn et al. (1986) used this test to differentiate between normal children and those with mild xerophthalmia. A study by Amedee-Manesme et al. (1988) has also shown that children with normal eyes but who were biologically vitamin A-deficient had abnormal conjunctival impression cytology. Further field trials are required to test the acceptability and efficacy of this technique.

For the Rose Bengal test one drop of a solution of Rose Bengal $(10 \mathrm{~g} / \mathrm{l})$ is instilled into the eye, and if xerosis is present clear pink spots are visible from a distance of $1 \mathrm{~m}$ (Vijayaraghavan et al. 1978). Despite the simplicity of this test it is not very sensitive or specific (Kusin et al. 1977).

\section{BIOCHEMICAL ASSESSMENT}

\section{Plasma retinol}

There are several problems associated with the interpretation of plasma retinol levels. Plasma levels only reflect body stores in two situations: first, when liver stores are depleted; second, when the liver is saturated with vitamin A, as in hypervitaminosis. Despite these problems plasma retinol levels $<100 \mu \mathrm{g} / \mathrm{l}$ tend to be associated with low liver stores and an increase in the prevalence of clinical signs and symptoms. Some of the problems with biochemical assessment of vitamin A deficiency are summarized by Underwood (1986). Interpretation of plasma levels $(\mu \mathrm{g} / \mathrm{l})$ as adopted by the WHO (1976) are as follows: $>500$ high, 200-500 normal, 100-200 low, $<100$ deficient. Where plasma retinol levels are used in surveys, the WHO has proposed that if the serum retinol level is $<100 \mu \mathrm{g} / \mathrm{l}$ in more than $5 \%$ of the at-risk population, hypovitaminosis is a major public health problem. The Pan-American Health Organization uses a level of $200 \mu \mathrm{g} / \mathrm{l}$ in $>15 \%$ of the population (Chopra \& Kevany, 1970). It is not really clear what level should be used because there are no studies of risk of morbidity and mortality in relation to different levels of vitamin A status.

\section{Liver biopsy}

Liver vitamin A levels give a true reflection of the body's status, but this technique is obviously not suitable for wide-scale use. A liver retinol level of $<20 \mu \mathrm{g} / \mathrm{g}$ is associated with depleted hepatic stores (Dorea, 1984).

\section{Relative dose response}

This test is based on the principle that when stores of retinol are high, plasma retinol is little affected by an oral or intravenous dose of vitamin A (Loerch et al. 1979). However, when the body stores are depleted or low the plasma retinol level following supplementation increases and reaches a peak at $5 \mathrm{~h}$. 
The validity of the relative dose response (RDR) has been reasonably well established in experimental studies in animals. There are also several human studies which support its use in future studies of vitamin A status (Campos et al. 1987). The RDR suffers from the disadvantage that two blood samples are necessary within $5 \mathrm{~h}$ of each other.

\section{IMMUNITY AND INFECTION}

There is no doubt that severe vitamin A deficiency predisposes the individual to infection. However, isolated vitamin A deficiency is a relatively rare occurrence in man. It is frequently associated with some degree of protein-energy malnutrition or other micronutrient deficiency (e.g. zinc, iron or copper), or both. These deficiencies themselves are well recognized as important influences on the immune system. The major problem has been to try to unravel the relative contributions of each of these deficiencies to immunological function. This subject is quite complicated, and it is reviewed elsewhere by Scrimshaw et al. (1968), Chandra \& Au (1981) and Tomkins \& Watson (1989).

\section{ANIMAL EXPERIMENTAL STUDIES}

There are several separate but interdependent host-defence mechanisms that a pathogen has to overcome if it is to produce an infection.

\section{Mucosal surfaces}

Vitamin $A$ is important in maintaining the integrity of epithelial surfaces. In deficiency states $(\mathrm{A}-$ ) there is stratification of the cells, followed by squamous metaplasia, and eventual keratinization (Chytill, 1985). These changes, accompanied by desquamation of cells and decreased mucus production, are widespread and allow micro-organisms which colonize mucosal surfaces to invade the body. Desquamation of cells may provide a nidus of infection, especially in the smaller airways. The loss of normal muco-ciliary function in the respiratory tract removes one of the important local host-defence mechanisms. Vitamin A-deficient rats have impaired DNA synthesis, and the turnover of their epithelial cells is much slower (Zile et al. 1977). Chandra (1988) noted increased bacterial adhesion to respiratory epithelium among children with vitamin $A$ deficiency. In a recent study by Ongsakul et al. (1985) the kinetics of blood clearance of injected Escherichia coli and the in vitro phagocytic activity of polymorph leucocytes were markedly depressed in A - rats. These effects were noted by $12 \mathrm{~d}$ after withdrawal of retinoic acid from the diet. Polymorph counts did not change as long as body-weight remained normal. Earlier studies which showed an increase in polymorph counts in A - animals may have been due to the effects of secondary infection (Gershwin et al. 1985). In another study an increase in splenic and lymph node macrophage proportions was noted, but only in the late stages of deficiency (Smith et al. 1987).

\section{Cell-mediated immunity}

Delayed hypersensitivity responses to the skin contact antigen, dinitrofluorobenzene, were noted in A - mice by Smith et al. (1987). These effects occurred early in the deficiency state (serum retinol levels of the $\mathrm{A}-$ mice were $50 \%$ of vitamin $\mathrm{A}$-adequate $(\mathrm{A}+$ ) mice) before there were any changes in the appetite or weight and before the occurrence of clinical signs.

In vitro studies of cell-mediated immunity have shown that mitogenic responses were significantly reudced in A- animals (Nauss et al. 1979). Mitogenic responses to 
concanavalin A, phytohaemagglutinin and lipopolysaccharide returned to normal within $3 \mathrm{~d}$ of vitamin A supplementation (Chandra \& Au, 1981). Retinoic acid was found to enhance natural killer (NK) cell activity (Goldfarb \& Herberman, 1981). These cells play an important role in control of infection. Interestingly, retinoic acid has been reported to inhibit the production of interferon, the latter being important in the activation of NK cells (Abb \& Deinhardt, 1980). The increased activity of NK cells resulting from retinoic acid supplementation may be due to the alteration in cell surface structure and an increase in cell-surface receptor expression.

Retinoids have also been found to improve the function of macrophages (Lotan, 1986). Improvement of phagocytic function of alveolar macrophages in particular was noted in rats, whilst in mice treatment with retinoic acid improved activity of peritoneal macrophages (Bruly-Rosset et al. 1981).

\section{Humoral immunity}

Sirisinha et al. (1980) showed that A - rats had lower levels of secretory component on immunofluorescence staining. There was no alteration in the levels of serum $\operatorname{IgA}$ and $\operatorname{IgG}$, but there was a slight decrease in antibody affinity in the $\mathbf{A}$ - rats. Smith et al. (1987) found that $\mathbf{A}$ - mice had decreased antibody responses to protein antigens; the effect was more pronounced with increasing duration of dietary deficiency. At the age of 6 weeks (when the serum retinol levels of the $A-$ mice were $46 \%$ that of the $A+$ mice) the serum levels of $\mathrm{IgG}_{1}$ and $\mathrm{IgG}_{3}$ in the $A-$ animals were $<30 \%$ those of the $A+$ animals, but there was no difference in the IgM levels. At the age of 8 weeks (when the retinol levels of the $A-$ mice were $20 \%$ of the $A+$ mice) the serum levels of $\operatorname{IgM}_{\text {, and }} \mathrm{IgG}_{1}$ and $\mathrm{IgG}_{3}$ of the $A-$ animals were $70,<30$ and $<3 \%$ respectively of the $A+$ mice. Interestingly there was no difference in the total serum IgG levels between the two groups if they were kept in a sterile environment. However, when exposed to pathogens the $\mathbf{A}-$ mice had significantly higher levels of serum IgG than the A + mice. This suggests that mucosal immune systems were weaker in the $\mathrm{A}$ - mice, thereby allowing easier access of pathogens. Once invasion had occurred there was evidently a satisfactory antibody response, indicating an intact humoral immunity in the presence of vitamin A deficiency. Other studies have shown less satisfactory antibody responses. Khrishnan et al. (1974) reported that there was a decrease in the antibody response to diphtheria toxoid in A - animals. Pruzansky \& Axelrod (1955) found that $\mathbf{A}$ - animals had a moderate decrease in antibody production to diphtheria toxoid.

\section{FREE RADICAL SCAVENGING}

Free radicals are highly reactive molecules that contain one or more unpaired electrons (Slater, 1984). They originate endogenously from metabolic processes or exogenously as components of air pollution, cigarette smoke, radiation or infection. These molecules can cause tissue damage by reacting with polyunsaturated fatty acids in cell membranes, nucleotides in DNA and critical sulphydryl bonds in proteins (Machlin \& Bendich, 1987). There is increasing evidence implicating free radicals in the pathogenesis of a number of infections, such as malaria, tuberculosis and acute bacterial infections (Thurnham, 1988). The body's major defence mechanism against free radical damage are the antioxidants or free radical scavengers. These include vitamins $A, C$ and $E$, caeruloplasmin, uric acid, bilirubin, catalase (EC 1.11.1.6), superoxide dismutase $(E C$ 1.15.1.1), and gluthathione peroxidase ( $E C$ 1.11 1.9) (Thurnham, 1988). The extent of the tissue damage thus depends on a balance between free radical production and the antioxidant defence system (Halliwell, 1987). $\beta$-Carotene has powerful scavenging activity and its anti-cancer properties 
may be related to its antioxidant activity (Halliwell, 1987). Thus far no work has been published on whether or not vitamin $A$ has an antioxidant role in acute systemic infections. However, it is postulated that a deficient intake of $\beta$-carotene and vitamin $\mathbf{A}$ would result in a decrease in the body's defence against the free radicals generated during acute sepsis. The situation may be worsened during infections which release free radicals and increase consumption of vitamin A, resulting in depletion of the body's retinol reserves. This has been demonstrated clearly for the impact of viral infection on vitamin $A$ as assessed by the RDR (Campos et al. 1987).

\section{MALNUTRITION-INFECTION INTERACTIONS IN MAN}

The problem facing any reviewer of malnutrition-infection relationships in human subjects is that single infections and isolated nutritional deficiency are the exceptions. Thus, careful attention to confounding variables is critical. Notwithstanding these problems there are several reports that indicate the important effect of vitamin $A$ on the outcome of infection.

Sirisinha et al. (1975) found that levels of secretory IgA in nasal washings of patients with protein-energy malnutrition and vitamin A deficiency were lower than in those with protein-energy malnutrition without vitamin A deficiency. Bhaskaram et al. (1986) found that secretory IgA and lysozyme contents of tears were significantly lower in children suffering from measles when compared to controls. The children with measles also had low serum retinol levels, but there was no correlation between the low retinol values and the immune factors in the tears. Mohanram et al. (1974) noted that the leucocyte content of lysozyme of A - children was significantly different from that of control subjects. Interestingly, there was no difference in plasma values, but the leucocyte lysozyme levels returned to normal with vitamin A supplementation.

Cell-mediated and humoral immune responses in children supplemented with a single dose of $60 \mathrm{mg}$ vitamin A were evaluated by Brown et al. (1980). They found no difference between the supplemented and control groups in terms of antibody following immunization with tetanus toxoid and delayed-type hypersensitivity responses to tuberculin and candida skin tests. Kutty et al. (1981) also noted similar concentrations of antibodies in A- and A + children. Bhaskaram \& Reddy (1975) found that nine A - children all had low-Tlymphocyte counts, even though total lymphocyte function was normal. Delayed-type hypersensitivity skin responses to phytohaemagglutinin were negative in five of the nine children. In a study performed over 30 years ago Jayalaskshmi \& Gopalan (1958) noted that the proportion of $\mathbf{A}$ - children who developed positive skin tests to tuberculin (defined as $>5 \mathrm{~mm}$ of induration) was less than that of a control group, but other possible differences between the groups were not described. Sidell et al. (1981) found no change in the response of blood lymphocytes from vitamin A-deficient subjects to in vitro stimulation, but when they added retinoic acid to human thymocytes and tonsillar lymphocytes they noted a twofold increase in response. They concluded that this difference was related to the higher proportion of immature cells in the thymus and tonsils these cells being more responsive to mitogenic stimulation.

A major problem facing all these investigators was the rather poor definition of vitamin A status. Now that various types of RDR assay are available it might be valuable to review the immune mechanisms more carefully. Overall it appears that there is relatively little impact of vitamin A on the humoral system but considerable suppression of cellular responses. 


\section{EPIDEMIOLOGICAL STUDIES}

Several large-scale community studies have been performed in recent years in an attempt to clarify the relationship between vitamin $A$ and infection. Sommer et al. (1984) followed up 4600 Indonesian preschool children with clinical examinations every 3 months for 18 months. They found that those with mild xerophthalmia at the beginning of a 6-month interval developed diarrhoeal disease twice as frequently and respiratory tract infections three times more frequently than the children with normal eyes. These findings were independent of nutritional status (weight/height) and age. Rates in well-nourished children with xerophthalmia were higher than in poorly nourished children with normal eyes. These results are striking, but some problems in the study design were noted. Possible confounding variables such as breast feeding, maternal education, access to health-care facilities and other socio-economic variables were not controlled. There was also no correlation with severity or duration of illness. Weight/height was the only anthropometric index used to compare Indian children in a study by Milton et al. (1987). However, their findings with respect to the increased occurrence of respiratory-tract infections in children with vitamin A deficiency were similar to the Indonesian study. No increase in diarrhoea was noted in the Indian study. In a longitudinal study of 3481 Indonesian preschool children, Sommer et al. (1986) found that the overall mortality rate in children with mild xerophthalmia (night blindness and Bitot's spots) was four times that of children with no eye changes. Mortality increased with increasing severity of disease, children with nightblindness and Bitot's spots having a rate nine times that of normal children.

\section{VITAMIN A SUPPLEMENTS AND INFECTIONS}

In view of the considerabie problems in assessing the degree of deficiency of vitamin $A$ in prospective studies of morbidity and mortality it has been helpful to have results of recently published intervention studies. Barclay et al. (1987) showed a reduction in case fatality rate from measles among Tanzanian children less than 2 years old if they were given $60 \mathrm{mg}$ vitamin A orally for $2 \mathrm{~d}$. Much larger prospective studies in Indonesia have examined the effect of a six-monthly dose of vitamin $A(60 \mathrm{mg})$ on mortality among preschool children. These types of study are fraught with epidemiological problems. Lack of baseline mortality and specific cause of death, information or lack of accurate information about access to health services by intervention and 'control' communities all contribute to the difficulties. Furthermore, the control villages in the Indonesian study had a high occurrence of xerophthalmia. Overall there was $34 \%$ lower mortality in the intervention group, but most of this occurred among older children (Sommer et al. 1986). A more recent study using fortification of monosodium glutamate among different Indonesian populations showed a similar reduction in mortality. The preschool children in the control villages died at 1.8 times the rate of children in programme villages (Muhilal et al. 1988).

The Tanzanian and Indonesian studies were all performed among communities where xerophthalmia is endemic and a marked effect of vitamin A supplementation is not unsuspected. It is, therefore, even more interesting to see the results of studies among populations where vitamin A deficiency is not endemic. Supplementation of Australian children with a history of frequent respiratory infections caused a reduction in attack rate for lower respiratory disease of $25 \%$ (Pinnock et al. 1986), the children received $450 \mathrm{mg} / \mathrm{kg}$ daily for about 11 months. None of the children was considered biochemically deficient on the basis of a single plasma retinol result. In a study of 189 black infants and children with severe measles in South Africa, half were given $60 \mathrm{mg}$ orally for two consecutive days and half received a placebo. There was a lower mortality, and morbidity rates were considerably 
improved in the vitamin A-supplemented group (G. Hussey, unpublished results). This is also particularly interesting because xerophthalmia is not endemic in the population. It seems reasonable to surmise that in both these studies the children under investigation were biochemically deficient in vitamin $A$, as judged by improvement in resistance to infection following supplementation. It may even be that the metabolic stress of the measles affected vitamin A status.

However, the findings from all the epidemiological studies presently available are not yet sufficient to confirm that children living in areas with apparently adequate vitamin $A$ intake should be given vitamin $A$ as an immune support-stimulant during infection. Information is most urgently needed by those who wish to reduce the mortality of children from diarrhoea and respiratory disease, as well as measles.

\section{PREVENTIVE SUPPLEMENTATION WITH VITAMIN A}

Where xerophthalmia is recognized there seems little doubt of the value of vitamin $A$ supplements in the prevention of blinding malnutrition and in the reduction in prevalence and complications of certain infections. Certain governments such as those of Indonesia and India have already taken the recent finding seriously, with a commitment to vitamin A supplementation in the Under Fives Health and Nutrition Programmes. However, most programmes still concentrate on the 12-60 month age-group. There are considerable problems for the infant, particularly those who are small at birth. Low-birth-weight infants may have severely deficient hepatic stores of vitamin $A$, rendering them susceptible to pulmonary dysplasia as well as intestinal and respiratory infections.

UNICEF and WHO are now advising a more active policy for the first year of life. Supplementation may begin immediately after birth by giving the mother $60 \mathrm{mg}$ after delivery. Concentration of vitamin $A$ in breast milk is increased by the addition of vitamin $A$ in monosodium glutamate (Muhilal et al. 1988), so it seems likely that an increase in breast-milk vitamin A would also occur as a result of a large oral dose to the mother. There is nothing in the literature on how high the vitamin A levels in breast milk go, or how long they remain elevated. A recent UNICEF-WHO strategy is for doses of vitamin $A$ to be given at the time of immunization, about 3-4 months for triple antigen and at 9 months for measles vaccine. These approaches are not in any way meant to displace the important need to increase the dietary intake of breast milk, green leafy vegetables and fruits rich in carotenoids, but they do recognize the difficulties in reaching adequate dietary levels experienced by poor deprived communities living in a hostile environment. Relatively cheap, multi-dose spray containers can now provide vitamin $A$ at all contacts between children and health services, but the value of these supplements in areas with little xerophthalmia or none at all is not at all clear. It seems important to develop and evaluate better methods for assessing vitamin $A$ status. In addition, it is essential to evaluate the effect of vitamin A for routine prophylaxis or clinical management in communities where vitamin A status is marginal. At the present time WHO and UNICEF have recommended that vitamin A should be given to any child with measles in any community where case fatality rates are $1 \%$ or greater. It seems rather important to establish the extent and limits of the beneficial effect of vitamin $A$ on immune mechanisms before recommending its use in nutrition and health programmes throughout the world.

\section{REFERENCES}

Abb, J. \& Deinhardt, F. (1980). Effects of retinoic acid on the human lymphocyte response to mitogens. Experimental Cell Biology 48, 169-179.

Amedee-Manesme, O., Luzeau, R., Wittpenn, J. R., Hanck, A. \& Sommer, A. (1988). Impression cytology detects subclinical vitamin A deficiency. American Journal of Clinical Nutrition 47, 875-878. 
Barclay, A. J. G., Foster, A. \& Sommer, A. (1987). Vitamin A supplements and mortality related to measles: a randomised clinical trial. British Medical Journal 294, 294-296.

Barker, B. M. (1983). Vitamin A. In Vitamins in Medicine, vol. 2, pp. 211-290 [B. M. Barker and D. A. Bender, editors]. London: W. Heinemann.

Bhaskaram, C. \& Reddy, V. (1975). Cell-mediated immunity in iron and vitamin deficient children. British Medical Journal iil, 522.

Bhaskaram, P., Mathur, R., Rao, V., Madhusudan, J., Radhakrishna, K., Raghuramulu, N. \& Reddy, V. (1986). Pathogenesis of corneal lesions in measles. Human Nutrition: Clinical Nutrition 40C, 197-204.

Brown, K. H., Rajan, M. M., Chakraborty, J. \& Aziz, K. M. A. (1980). Failure of a large dose of vitamin A to enhance the antibody response to tetanus toxoid in children. American Journal of Clinical Nutrition 33, $212-217$.

Bruley-Rosset, M., Hercend, T., Martinez, J., Rappaport, H. \& Mathé, G. (1981). Prevention of spontaneous tumors of aged mice by immunopharmacologic manipulation. Study of immune antitumor mechanisms. Journal of the National Cancer Institute 66, 1113-1119.

Campos, F. A. C. S., Flores, H. \& Underwood, B. A. (1987). Effect of an infection on vitamin A status of children as measured by the relative dose response. American Journal of Clinical Nutrition 46, 91-94.

Chandra, R. K. (1988). Increased bacterial binding to respiratory epithelial cells in vitamin A deficiency. British Medical Journal 297, 834-835.

Chandra, R. K. \& Au, B. (1981). Single nutrient deficiency and cell-mediated immune responses. III. Vitamin A. Nutrition Research 1, 181-185.

Chopra, J. G. \& Kevany, J. (1970). Hypovitaminosis A in the Americas. American Journal of Clinical Nutrition 23, 231-241.

Chytill, F. (1985). Function of vitamin A in the respiratory tract. Acta Vitaminologica et Enzymologica 7 (suppl.), 27-31.

Dorea, J. G., Souza, J. A., Galvão, M. O. \& Iunes, M. A. F. (1984). Concentration of vitamin A in the liver of foetuses and infants dying of various causes in Brasilia, Brazil. International Journal of Vitamin and Nutrition Research 54, 119-123.

Favaro, R. M. D., de Souza, N. V., Batistal, S. M., Ferriani, M. G. C., Desai, I. D. \& de Oliveira, J. E. D. (1986). Vitamin A status of young children in Southern Brazil. American Journal of Clinical Nutrition 43, 852-858.

Gershwin, M. E., Beach, R. S. \& Hurley, L. S. (1985). Nutrition and Immunity, pp. 228-239. New York: Academic Press.

Goldfarb, R. H. \& Herberman, R. B. (1981). Natural killer cell reactivity: regulatory interactions among phorbol esters, interferon, cholera toxin, and retinoic acid. Journal of Immunology 126, 2129-2135.

Goodman, D. S. (1984). Vitamin A and retinoids in health and disease. New England Journal of Medicine 310, I023-1031.

Halliwell, B. (1987). Oxidants and human disease: some new concepts. FASEB Journal 1, 358-364.

Hatchell, D. \& Sommer, A. (1986). Detection of early xerophthalmia by impression cytology. Archives of Ophthalmology 104, 237-239.

Jayalakshmi, V. T. \& Gopalan, C. (1958). Nutritional tuberculosis. I. An epidemiological study. Indian Journal of Medicine 46, 87-92.

Krishnan, S., Bhuyan, U. N., Talwar, G. P. \& Ramalingaswami, V. (1974). Effect of vitamin A and protein-calorie undernutrition on immune responses. Immunology 27, 383-392.

Kusin, J. A., Sinaga, H. S. R. P. \& Marpaung, A. M. (1977). Xerophthalmia in North Sumatra. Tropical and Geographical Medicine 29, 41-46.

Kutty, P. M., Mohantam, M. \& Reddy, V. (1981). Humoral immune responses in vitamin A deficiency children. Acta Vitaminologica et Enzymologica 4, 231-235.

Loerch, J. D., Underwood, B. A. \& Lewis, K. C. (1979). Response of plasma levels of vitamin A to a dose of vitamin $A$ as an indicator of hepatic vitamin $A$ reserve in rats. Journal of Nutrition 109, 778-786.

Lotan, R. (1986). Vitamin A and mechanisms of immunity. In Proceedings of the XIIIth International Congress of Nutrition, 1985, pp. $471-474$ [T. G. Taylor and N. K. Jenkins, editors]. London: John Libbey.

Machlin, L. J. \& Bendich, A. (1987). Free radical tissue damage: protective role of antioxidant nutrients. $F A S E B$ Journal 1, $441-445$.

Madani, K. A. (1986). Retinoic acid: a general overview. Nutrition Research 6, 107-123.

Mellanby, E. \& Green, H. N. (1929). Vitamin A as an anti-infective agent. British Medical Journal i, 984-986.

Milton, R. C., Reddy, V. \& Naidu, A. N. (1987). Mild vitamin A deficiency and childhood morbidity-an Indian experience. American Journal of Clinical Nutrition 46, 827-829.

Mohanram, M.. Reddy, V. \& Mishra, S. (1974). Lysozyme activity in plasma and leucocytes in malnourished children. British Journal of Nutrition 32, 313-316.

Muhilal, D. P., Idjradinata, Y. R. \& Muherdiyantiningsih, D. K. (1988). Vitamin A-fortified monosodium glutamate and health, growth, and survival of children: a controlled field trial. American Journal of Clinical Nutrtion 48, 1271-1276.

Natadisastra, G., Wittpenn, J. R., West, K. P., Muhilal, D. P. \& Sommer, A. (1987). Impression cytology for detection of vitamin A deficiency. Archives of Ophthalmology 105, 1224-1228.

Nauss, K. M., Mark, D. A. \& Suskind, R. M. (1979). Effect of vitamin A deficiency on the in vitro cellular immune response of rats. Journal of Nutrition 109, 1815-1823. 
Olson. J. A. (1987). Recommended dietary intakes of vitamin A in humans. American Journal of Clinical Nutrition 45, 704-716.

Ong. D. E. (1985). Vitamin A-binding proteins. Nutrition Review's 43, 225-232.

Ongsakul, M., Sirisinha, S. \& Lamb, A. J. (1985). Impaired blood clearance of bacteria and phagocytic activity in vitamin A-deficient rats. Proceedings of the Society for Experimental Biology and Medicine 178, $204-208$.

Orten, J. M. \& Nehaus, O. W. (1982). Human Biochemistry, 10th ed., pp. 734-746. St Louis, MO: C. V. Mosby.

Pinnock, C. B., Douglas, R. M. \& Badcock, N. R. (1986). Vitamin A status in children who are prone to respiratory tract infections. Australian Paediatric Journal 22, 95-99.

Pitt, G. A. J. (1981). The assessment of vitamin A status. Proceedings of the Nutrition Society 40, $173-178$.

Pruzansky, J. \& Axelrod. A. E. (1955). Antibody production to diphtheria toxoid in vitamin deficiency states. Proceeding.s of the Society for Experimental Biology and Medicine 89, 323-325.

Scrimshaw, N. S., Taylor, C. E. \& Gordon, J. E. (1968). Interaction of Nutrition and Infection. WHO Monograph Series no. 57. Geneva: World Health Organization.

Sidell, N., Famatiga, E. \& Golub, S. H. (1981). Augmentation of human thymocyte proliferative responses by retinoic acid. Experimental Cell Biology 49, 239-245.

Sirisinha, S., Darip, M. D., Moongkarndi, P., Ongsakul, M. \& Lamb, A. J. (1980). Impaired local immune response in vitamin A-deficient rats. Clinical and Experimental Immunology 40, 127-135.

Sirisinha, S., Suskind, R., Edelman, R., Asvapaka, C. \& Olson, R. E. (1975). Secretory and serum IgA in children with protein-calorie malnutrition. Pediatrics 55, 166-170,

Slater, T. F. (1984). Free-radical mechanisms in tissue injury. Biochemical Journal 222, 1-15.

Smith, S. M., Levy , N. S. \& Hayes, C. E. (1987). Impaired immunity in vitamin A-deficient mice. Journal of Nutrition 117, 857-865.

Sommer, A., Katz, J. \& Tarwotjo, I. (1984). Increased risk of respiratory disease and diarrhea in children with preexisting mild vitamin A deficiency. American Journal of Clinical Nutrition 40, 1090-1095.

Sommer, A., Tarwotjo. I.. Djunaedi, E., West, K. P., Loeden, A. A., Tilden, R. \& Mele, L. (1986). Impact of vitamin A supplementation on childhood mortality. A randomised controlled community trial. Lancet $i$, $1169-1173$.

Sommer, A., Tarwotjo, I., Huissaini, G. \& Susanto, D. (1983). Increased mortality in children with mild vitamin A deficiency. Lancet ii, 585-588.

Thurnham, D. (1988). Vitamin C (ascorbic acid): antioxidant functions of vitamin $C$ in disease in man and animals. In Comparative Nutrition, pp. 91-103 [K. L. Blaxter and 1. MacDonald, editors]. London: John Libbey.

Tomkins, A. M. \& Watson, F. (1989). Malnutrition and Infection. A Review. Geneva: World Health Organization.

Underwood, B. A. (1986). Vitamin status, carotene and cancer prevention. In Proceedings of the XIIITh International Congress of Nutrition, 1985, pp. 474-477 [T. G. Taylor and N. K. Jenkins, editors]. London: John Libbey.

Vijayaraghavan, K., Sarma, K. V. R., Reddy, V. \& Bhaskaram, P. (1978). Rose Bengal staining for detection of conjunctival xerosis in nutrition surveys. American Journal of Clinical Nutrition 31, 892-894.

Vinton, N. E. \& Russell, R. M. (1981). Evaluation of a rapid test of dark adaptation. American Journal of Clinical Nutrition 34, 1961-1966.

Wittpenn, J., Tseng, S. \& Sommer, A. (1986). Detection of early xerophthalmia by impression cytology. Archives of Ophthalmology 104, 237-239.

World Health Organization (1976). Vitamin A Deficiency and Xerophthalmia. WHO Technical Report Series, no. 590. Geneva: WHO.

Zile, M., Bunge, E. C. \& DeLuca, H. (1977). Effect of vitamin A deficiency on intestinal cell proliferation in the rat. Journal of Nutrition 107, $552-560$. 